PROCEEDINGS OF THE YEREVAN STATE UNIVERSITY

Chemistry and Biology

2021, 55(2), p. 189-195

Biology

\title{
FEATURES OF CHANGES IN CARDIAC ACTIVITY UNDER VIBRATION EXPOSURE
}

\author{
S. M. MINASYAN, E. S. GEVORKYAN *, Ts. I. ADAMYAN, \\ S. H. SARGSYAN, L. E. GHUKASYAN \\ Chair of Human and Animal Physiology, YSU, Armenia
}

The results of the study have shown that when exposed to vibration, changes in cardiac activity occur in rabbits, the nature and direction of which depend on the parameters of the dynamic factor. Vibration with a frequency of $20 \mathrm{~Hz}$ causes moderate tachycardia, and 40 and $80 \mathrm{~Hz}$ - severe tachycardia. Three months of vibration in the first month of exposure causes tachycardia, and after three months of exposure, bradycardia. There is also a reduction in respiratory movements and a decrease in the activity of the enzyme succinate dehydrogenase.

https://doi.org/10.46991/PYSU:B/2021.55.2.189

Keywords: electrocardiogram, vibration exposure, succinate dehydrogenase, cardiovascular system.

Introduction. The problem of the biological nature of vibration exposure is one of the most important in biomedicine. In the era of modern civilization, mechanical stress in the form of vibrations is gaining increasing importance in human life, becoming a part of the environment and an etiological factor [1-3].

Although over the past decades the problem of vibration has been studied very intensively, and the attention of many specialists in various fields of science has been focused on it, its development in the theoretical aspect is still lagging behind the demands of practice.

A number of experimental and clinical studies have been devoted to the study of the effect of vibration on the body and, in particular, the cardiovascular system, but many questions remain unclear and are often interpreted in different ways by various researchers. In the literature, the capillary blood circulation and the tone of peripheral vessels are covered with sufficient completeness; however, the functional state of cardiac activity during vibration of a single and repeated exposure to it has not been studied enough. This circumstance was the reason for this experimental study of the influence of vibration with a frequency of 20,40 and $80 \mathrm{~Hz}$ and of different amplitudes on the cardiac activity of rabbits. The parameters used were close to those in manufacturing.

Materials and Methods. The research was carried out in two series of experiments. In the first series, the effect of vibration of various frequencies on the ECG of rabbits was studied. ECGs were recorded before and during vibration, as

* E-mail: emma.gevorkyan@ysu.am (corresponding author) 
well as within 30 minutes after the period after vibration. The animals were exposed to vibration on a ST-300 vibration stand for 30 minutes (with the parameters of frequency, amplitude and maximum acceleration: $20 \mathrm{~Hz}, 1 \mathrm{~mm} ; 40 \mathrm{~Hz}, 0.8 \mathrm{~mm}$, 6-7×g; and $80 \mathrm{~Hz}, 0.6 \mathrm{~mm}, 19.7 \times \mathrm{g})$. ECGs were recorded on an 8-channel encephalograph of the "Alvar" company in 3 standard leads at a tape pulling speed of 30 and $60 \mathrm{~mm} / \mathrm{sec}$. During vibration, in order to eliminate interference during ECG recording, we used a special method of fixing animals on a vibration platform. A metal box was rigidly fixed on the vibrating platform for the simultaneous placement of 2 rabbits. Animals in the box were in a free position. The top of the box was covered with a canvas hood with holes for free breathing of animals. The measurements of the amplitudes of the general vibration of this vibrating unit were carried out using a vibrometer AV-43. It should be noted that the operation of the shaker was accompanied by low-frequency noise (75 dB), which was measured with a sound level meter. Control animals were tested for their response to 1.5-hour fixation on the platform and to the noise of the vibrating stand for 30 minutes.

The oxygen uptake by the cardiac muscle tissue was also determined by the Warburg manometric method. For this, the animals were decapitated and the cardiac muscle was extracted. The criterion for the intensity of tissue respiration was the amount of oxygen absorbed by $1 \mathrm{mg}$ of tissue (dry weight) in $\mu \mathrm{L}$ of $\mathrm{O}_{2}$ per hour. In parallel with the study of tissue respiration, the activity of the succinate dehydrogenase (SDH) enzyme was also determined by the method of bleaching of methylene blue, the principle of which is that succinic acid is converted to fumaric acid when exposed to SDH. The enzyme transfers hydrogen ions from succinic acid to methylene blue, as a result of which the latter is discolored. The SDH activity was expressed by the duration of the reaction. The obtained quantitative data were subjected to computer statistical processing.

Results and Discussion. In intact rabbits, the heart rate ranged from 270 to 324 beats per minute. The results of the study of ECG waves and intervals are shown in Table 1 . Vibration with a frequency of $20 \mathrm{~Hz}$ caused moderate tachycardia. So, 5 minutes after turning on the vibration stand, there was an increase in heart rate by 16 beats per minute. The maximum sympathotonic effect was recorded at 20 minutes of vibration, which exceeded the initial level by 44 beats per minute $(\mathrm{P}<0.001)$. The restoration of the initial rhythm was noted by the 30th minute of the post-vibration period.

Exposure to vibration with a frequency of $40 \mathrm{~Hz}$ in almost all animals led to an increase in heart rate: by 5 minutes, the number of heart beats increased by 23 beats per minute, reaching a maximum (54 beats) by 20 minutes. At the same time, changes in ECG voltage were insignificant (Tab. 1).

High-frequency vibration $(80 \mathrm{~Hz})$ produced a pronounced tachycardic effect in rabbits. As can be seen from Table 1, at 20 minutes of exposure to vibration, there was an increase in heart rate by 68 beats per minute, a decrease in the $\mathrm{P}$ wave, an increase in the $\mathrm{R}$ and $\mathrm{T}$ voltages. A decrease in the $\mathrm{S}$ wave voltage was also noted, and in some rabbits it was not recorded at all. The changes in the metabolism of the heart muscle are also evidenced by the results of an increase in oxygen uptake and SDH activity. After 30 minutes of vibration at a frequency of $80 \mathrm{~Hz}$, an increase in myocardial oxygen uptake and an increase in SDH activity by $62 \%$ were found. 
S. M. MINASYAN, E. S. GEVORKYAN *, Ts. I. ADAMYAN, et al.

Table 1

The main ECG indexes in rabbits when exposed to vibration

\begin{tabular}{|c|c|c|c|c|c|c|c|c|c|c|}
\hline \multirow{2}{*}{ 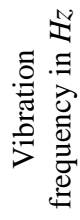 } & \multirow{2}{*}{ 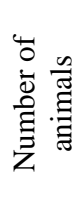 } & \multirow{2}{*}{$\begin{array}{l}\text { ECG } \\
\text { index }\end{array}$} & \multirow{2}{*}{$\begin{array}{c}\text { Before } \\
\text { vibration }\end{array}$} & \multicolumn{4}{|c|}{$\begin{array}{l}\text { Time since the start of vibration } \\
\text { in } \min \end{array}$} & \multicolumn{3}{|c|}{$\begin{array}{l}\text { Time after vibration } \\
\text { in } \min \end{array}$} \\
\hline & & & & 5 & 10 & 20 & 30 & 10 & 20 & 30 \\
\hline 20 & 10 & Heart rate & $\begin{array}{c}281 \\
\pm 6.12\end{array}$ & $\begin{array}{c}297 \\
\pm 6.22 \\
\mathrm{P} \leq 0.1\end{array}$ & $\begin{array}{c}304 \\
\pm 3.73 \\
\mathrm{P} \leq 0.001\end{array}$ & $\begin{array}{c}325 \\
\pm 3.92 \\
\mathrm{P} \leq 0.001\end{array}$ & $\begin{array}{c}312 \\
\pm 2.37 \\
\mathrm{P} \leq 0.001\end{array}$ & $\begin{array}{c}300 \\
\pm 2.95 \\
\mathrm{P} \leq 0.01\end{array}$ & $\begin{array}{c}289 \\
\pm 2.14 \\
\mathrm{P} \leq 0.2\end{array}$ & $\begin{array}{c}283 \\
\pm 2.46 \\
\mathrm{P} \leq 0.5\end{array}$ \\
\hline \multirow{4}{*}{40} & \multirow{4}{*}{10} & Heart rate & $\begin{array}{c}275 \\
\pm 5.21\end{array}$ & $\begin{array}{c}298 \\
\pm 6.81 \\
\mathrm{P} \leq 0.01 \\
\end{array}$ & $\begin{array}{c}309 \\
\pm 3.74 \\
\mathrm{P} \leq 0.001\end{array}$ & $\begin{array}{c}329 \\
\pm 2.83 \\
\mathrm{P} \leq 0.001 \\
\end{array}$ & $\begin{array}{c}314 \\
\pm 7.26 \\
\mathrm{P} \leq 0.001\end{array}$ & $\begin{array}{c}300 \\
\pm 4.64 \\
\mathrm{P} \leq 0.001 \\
\end{array}$ & $\begin{array}{c}282 \\
\pm 5.86 \\
P \leq 0.5\end{array}$ & $\begin{array}{c}281 \\
\pm 7.24 \\
\mathrm{P} \leq 0.5\end{array}$ \\
\hline & & $\begin{array}{c}\text { P wave } \\
\text { amplitude } \\
\text { in } m V\end{array}$ & $\begin{array}{c}0.17 \\
\pm 0.02\end{array}$ & $\begin{array}{c}0.14 \\
\pm 0.01 \\
\mathrm{P} \leq 0.2\end{array}$ & $\begin{array}{c}0.13 \\
\pm 0.01 \\
\mathrm{P} \leq 0.1\end{array}$ & $\begin{array}{c}0.12 \\
\pm 0.03 \\
\mathrm{P} \leq 0.2\end{array}$ & $\begin{array}{c}0.14 \\
\pm 0.01 \\
\mathrm{P} \leq 0.2\end{array}$ & $\begin{array}{c}0.15 \\
\pm 0.02 \\
\mathrm{P} \leq 0.5\end{array}$ & $\begin{array}{c}0.16 \\
\pm 0.01 \\
\mathrm{P} \leq 0.5\end{array}$ & $\begin{array}{c}0.17 \\
\pm 0.01 \\
\mathrm{P} \leq 0.5\end{array}$ \\
\hline & & $\begin{array}{c}\text { R wave } \\
\text { amplitude } \\
\text { in } m V\end{array}$ & $\begin{array}{l}0.19 \\
\pm 0.2\end{array}$ & $\begin{array}{c}0.18 \\
\pm 0.01 \\
\mathrm{P} \leq 0.5\end{array}$ & $\begin{array}{c}0.19 \\
\pm 0.01 \\
\mathrm{P} \leq 0.5\end{array}$ & $\begin{array}{c}0.23 \\
\pm 0.02 \\
\mathrm{P} \leq 0.2\end{array}$ & $\begin{array}{c}0.22 \\
\pm 0.02 \\
\mathrm{P} \leq 0.2\end{array}$ & $\begin{array}{c}0.20 \\
\pm 0.03 \\
\mathrm{P} \leq 0.5\end{array}$ & $\begin{array}{c}0.19 \\
\pm 0.01 \\
\mathrm{P} \leq 0.5\end{array}$ & $\begin{array}{r}0.18 \\
\pm 0.02 \\
\mathrm{P} \leq 0.5\end{array}$ \\
\hline & & $\begin{array}{c}\text { T wave } \\
\text { amplitude } \\
\text { in } m V\end{array}$ & $\begin{array}{c}0.18 \\
\pm 0.01\end{array}$ & $\begin{array}{c}0.17 \\
\pm 0.01 \\
\mathrm{P} \leq 0.5\end{array}$ & $\begin{array}{c}0.19 \\
\pm 0.02 \\
\mathrm{P} \leq 0.5\end{array}$ & $\begin{array}{c}0.20 \\
\pm 0.01 \\
\mathrm{P} \leq 0.2\end{array}$ & $\begin{array}{c}0.21 \\
\pm 0.02 \\
\mathrm{P} \leq 0.2\end{array}$ & $\begin{array}{r}0.19 \\
\pm 0.01 \\
\mathrm{P} \leq 0.5\end{array}$ & $\begin{array}{c}0.18 \\
\pm 0.03 \\
\mathrm{P} \leq 0.5\end{array}$ & $\begin{array}{r}0.16 \\
\pm 0.03 \\
\mathrm{P} \leq 0.5\end{array}$ \\
\hline \multirow{4}{*}{80} & \multirow{4}{*}{15} & Heart rate & $\begin{array}{r}280 \\
\pm 4.90\end{array}$ & $\begin{array}{c}301 \\
\pm 3.76 \\
\mathrm{P} \leq 0.001 \\
\end{array}$ & $\begin{array}{c}315 \\
\pm 2.19 \\
\mathrm{P} \leq 0.001\end{array}$ & $\begin{array}{r}348 \\
\pm 11.72 \\
P \leq 0.001 \\
\end{array}$ & $\begin{array}{c}319 \\
\pm 3.63 \\
\mathrm{P} \leq 0.001 \\
\end{array}$ & $\begin{array}{c}323 \\
\pm 4.27 \\
\mathrm{P} \leq 0.001 \\
\end{array}$ & $\begin{array}{c}296 \\
\pm 7.14 \\
\mathrm{P} \leq 0.1\end{array}$ & $\begin{array}{r}285 \\
\pm 9.35 \\
\mathrm{P} \leq 0.5\end{array}$ \\
\hline & & $\begin{array}{c}\text { P wave } \\
\text { amplitude } \\
\text { in } m V\end{array}$ & $\begin{array}{c}0.17 \\
\pm 0.01\end{array}$ & $\begin{array}{r}0.14 \\
\pm 0.02 \\
\mathrm{P} \leq 0.2 \\
\end{array}$ & $\begin{array}{c}0.15 \\
\pm 0.03 \\
\mathrm{P} \leq 0.5\end{array}$ & $\begin{array}{c}0.12 \\
\pm 0.02 \\
\mathrm{P} \leq 0.05 \\
\end{array}$ & $\begin{array}{r}0.14 \\
\pm 0.01 \\
\mathrm{P} \leq 0.05\end{array}$ & $\begin{array}{c}0.16 \\
\pm 0.03 \\
\mathrm{P} \leq 0.5 \\
\end{array}$ & $\begin{array}{c}0.15 \\
\pm 0.01 \\
P \leq 0.2\end{array}$ & $\begin{array}{r}0.16 \\
\pm 0.02 \\
\mathrm{P} \leq 0.5\end{array}$ \\
\hline & & $\begin{array}{c}\text { R wave } \\
\text { amplitude } \\
\text { in } m V\end{array}$ & $\begin{array}{c}0.24 \\
\pm 0.02\end{array}$ & $\begin{array}{r}0.25 \\
\pm 0.02 \\
\mathrm{P} \leq 0.5\end{array}$ & $\begin{array}{c}0.31 \\
\pm 0.04 \\
\mathrm{P} \leq 0.5\end{array}$ & $\begin{array}{c}0.34 \\
\pm 0.04 \\
\mathrm{P} \leq 0.05 \\
\end{array}$ & $\begin{array}{r}0.32 \\
\pm 0.02 \\
\mathrm{P} \leq 0.5\end{array}$ & $\begin{array}{r}0.29 \\
\pm 0.03 \\
\mathrm{P} \leq 0.5\end{array}$ & $\begin{array}{c}0.28 \\
\pm 0.04 \\
P \leq 0.5\end{array}$ & $\begin{array}{r}0.26 \\
\pm 0.03 \\
\mathrm{P} \leq 0.5\end{array}$ \\
\hline & & $\begin{array}{c}\text { T wave } \\
\text { amplitude } \\
\text { in } m V\end{array}$ & $\begin{array}{c}0.15 \\
\pm 0.01\end{array}$ & $\begin{array}{c}0.12 \\
\pm 0.01 \\
\mathrm{P} \leq 0.05\end{array}$ & $\begin{array}{c}0.20 \\
\pm 0.03 \\
\mathrm{P} \leq 0.1\end{array}$ & $\begin{array}{c}0.20 \\
\pm 0.02 \\
\mathrm{P} \leq 0.05\end{array}$ & $\begin{array}{c}0.19 \\
\pm 0.03 \\
\mathrm{P} \leq 0.2\end{array}$ & $\begin{array}{c}0.20 \\
\pm 0.04 \\
\mathrm{P} \leq 0.2\end{array}$ & $\begin{array}{c}0.16 \\
\pm 0.03 \\
\mathrm{P} \leq 0.5\end{array}$ & $\begin{array}{r}0.16 \\
\pm 0.02 \\
\mathrm{P} \leq 0.5\end{array}$ \\
\hline
\end{tabular}

At medium and high frequencies ( 40 and $80 \mathrm{~Hz}$ ), the amplitude and frequency of respiratory movements in rabbits increased by $22 \%$ and $34 \%$, respectively.

In the second series of experiments, the animals were subjected to a threemonth exposure to vibration with a frequency of $80 \mathrm{~Hz}$, an amplitude of $0.4 \mathrm{~mm}$ and a duration of 3 hours. The ECG was recorded on the 10th, 20th and 30th days, and then monthly after vibration exposure. On these study days, as a functional test, the animals were subjected to short-term (30 minutes) exposure to a physical factor. During the first month, an increase in heart rate and respiratory movements was recorded. On the 30th day of vibration, the number of heart beats in the experimental rabbits increased by 58 beats per minute, and the respiratory rate increased by $22 \%$. At the same time, there was a decrease in the PQ and QT intervals, an increase in the $\mathrm{R}$ wave (table 2). During the test vibration, an increase in heart rate was observed, while the wave amplitude did not undergo significant changes (Tab. 2). 
Table 2

Dynamics of the main ECG indexes in rabbits during a three-month exposure to vibration

\begin{tabular}{|c|c|c|c|c|c|c|c|c|}
\hline & & 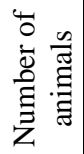 & Heart rate & $\begin{array}{l}\text { PQ interval } \\
\text { in seconds }\end{array}$ & $\begin{array}{l}\text { QT interval } \\
\text { in seconds }\end{array}$ & $\begin{array}{c}\text { P wave } \\
\text { amplitude } \\
\text { in } m V\end{array}$ & $\begin{array}{c}\text { R wave } \\
\text { amplitude } \\
\text { in } m V\end{array}$ & $\begin{array}{c}\text { T wave } \\
\text { amplitude } \\
\text { in } m V\end{array}$ \\
\hline \multirow{4}{*}{ 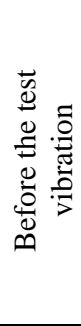 } & $\begin{array}{l}\text { Control } \\
\text { group }\end{array}$ & 15 & $282 \pm 5.21$ & $0.073 \pm 0.004$ & $0.175 \pm 0.008$ & $0.10 \pm 0.014$ & $0.24 \pm 0.028$ & $0.14 \pm 0.16$ \\
\hline & 30 & 10 & $\begin{array}{c}320 \pm 6.13 \\
P \leq 0.001\end{array}$ & $\begin{array}{c}0.52 \pm 0.002 \\
\mathrm{P} \leq 0.001\end{array}$ & $\begin{array}{c}0.152 \pm 0.004 \\
P \leq 0.02\end{array}$ & $\begin{array}{c}0.09 \pm 0.008 \\
\mathrm{P} \leq 0.5\end{array}$ & $\begin{array}{c}0.31 \pm 0.034 \\
P \leq 0.02\end{array}$ & $\begin{array}{c}0.20 \pm 0.022 \\
\mathrm{P} \leq 0.02\end{array}$ \\
\hline & 60 & 8 & $\begin{array}{c}185 \pm 7.65 \\
\mathrm{P} \leq 0.001\end{array}$ & $\begin{array}{c}0.089 \pm 0.004 \\
P \leq 0.01\end{array}$ & $\begin{array}{c}193 \pm 0.008 \\
\mathrm{P} \leq 0.05\end{array}$ & $\begin{array}{c}0.05 \pm 0.009 \\
\mathrm{P} \leq 0.01\end{array}$ & $\begin{array}{c}0.15 \pm 0.026 \\
P \leq 0.02\end{array}$ & $\begin{array}{c}0.07 \pm 0.017 \\
\mathrm{P} \leq 0.01\end{array}$ \\
\hline & 90 & 7 & $\begin{array}{c}191 \pm 6.35 \\
\mathrm{P} \leq 0.001 \\
\end{array}$ & $\begin{array}{c}0.092 \pm 0.002 \\
\mathrm{P} \leq 0.001\end{array}$ & $\begin{array}{c}0.201 \pm 0.007 \\
\mathrm{P} \leq 0.02\end{array}$ & $\begin{array}{c}0.06 \pm 0.007 \\
P \leq 0.02\end{array}$ & $\begin{array}{c}0.16 \pm 0.031 \\
\mathrm{P} \leq 0.05\end{array}$ & $\begin{array}{c}0.06 \pm 0.015 \\
\mathrm{P} \leq 0.001\end{array}$ \\
\hline \multirow{4}{*}{ 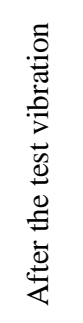 } & $\begin{array}{c}\text { Control } \\
\text { group }\end{array}$ & 15 & $\begin{array}{c}340 \pm 5.35 \\
\mathrm{P} \leq 0.001 \\
\end{array}$ & $\begin{array}{c}0.056 \pm 0.003 \\
\mathrm{P} \leq 0.001\end{array}$ & $\begin{array}{c}0.141 \pm 0.006 \\
\mathrm{P} \leq 0.001\end{array}$ & $\begin{array}{c}0.09 \pm 0.009 \\
\mathrm{P} \leq 0.5\end{array}$ & $\begin{array}{c}0.34 \pm 0.014 \\
\mathrm{P} \leq 0.01 \\
\end{array}$ & $\begin{array}{c}0.20 \pm 0.019 \\
\mathrm{P} \leq 0.02 \\
\end{array}$ \\
\hline & 30 & 10 & $\begin{array}{c}352 \pm 7.15 \\
\mathrm{P} \leq 0.01\end{array}$ & $\begin{array}{c}0.054 \pm 0.004 \\
\mathrm{P} \leq 0.5\end{array}$ & $\begin{array}{c}0.148 \pm 0.007 \\
\mathrm{P} \leq 0.5\end{array}$ & $\begin{array}{c}0.10 \pm 0.006 \\
\mathrm{P} \leq 0.5\end{array}$ & $\begin{array}{c}0.31 \pm 0.027 \\
\mathrm{P} \leq 0.5\end{array}$ & $\begin{array}{c}0.21 \pm 0.032 \\
\mathrm{P} \leq 0.5\end{array}$ \\
\hline & 60 & 8 & $\begin{array}{c}170 \pm 8.30 \\
\mathrm{P} \leq 0.2 \\
\end{array}$ & $\begin{array}{c}0.075 \pm 0.005 \\
\mathrm{P} \leq 0.5\end{array}$ & $\begin{array}{c}0.173 \pm 0.005 \\
\mathrm{P} \leq 0.2 \\
\end{array}$ & $\begin{array}{c}0.04 \pm 0.008 \\
\mathrm{P} \leq 05\end{array}$ & $\begin{array}{c}0.12 \pm 0.045 \\
\mathrm{P} \leq 0.5\end{array}$ & $\begin{array}{c}0.08 \pm 0.023 \\
\mathrm{P} \leq 0.5 \\
\end{array}$ \\
\hline & 90 & 7 & $\begin{array}{c}172 \pm 8.55 \\
\mathrm{P} \leq 0.1\end{array}$ & $\begin{array}{c}0.091 \pm 0.006 \\
\mathrm{P} \leq 0.5\end{array}$ & $\begin{array}{c}0.203 \pm 0.008 \\
P \leq 0.5\end{array}$ & $\begin{array}{c}0.05 \pm 0.007 \\
\mathrm{P} \leq 0.5\end{array}$ & $\begin{array}{c}0.17 \pm 0.035 \\
\mathrm{P} \leq 0.5\end{array}$ & $\begin{array}{c}0.084 \pm 0.017 \\
P \leq 0.2\end{array}$ \\
\hline
\end{tabular}

There was also observed an increase in oxygen consumption and an increase in SDH activity in the myocardium. An increase in oxygen uptake in animals exposed to vibration of different frequencies has also been observed in other studies $[4,5]$.

In the second month of exposure to vibration, the number of heart contractions decreased by $30 \%$ and a decrease in the voltage of the $\mathrm{R}$ and $\mathrm{T}$ waves was recorded. One of the most frequent electrographic signs was an increase in the duration of the electrical systole of the ventricles of the heart (Tab. 2). Compared with intact rabbits, a slight slowdown in atrioventricular conduction was also observed.

The bradycardic effect persisted after three months of exposure to vibration. On the 90th day of the study, the animals had a heart rate of 191 beats per minute. In experimental animals during this period, a significant decrease in the voltage of the $\mathrm{P}$ and $\mathrm{R}$ waves was observed (Tab. 2). The $\mathrm{T}$ wave voltage was lower than in control animals. It was often smoothed out. There were also noted signs of impaired atrioventricular and intraventricular conduction. The PQ interval on the 90th day of the study was lengthened by $28 \%(\mathrm{P}<0.001)$, and the QT interval by $18 \%(\mathrm{P}<0.001)$.

The changes in the metabolism of the heart muscle are also evidenced by the results on oxygen uptake and SDH activity. On the 90th day, the activity of the SDH enzyme decreased by $28 \%$, which indicates the effect of prolonged vibration on the metabolic process occurring at the level of enzymes in the cells of the heart muscle. During this period, after the test vibration, in $60 \%$ of the rabbits the heart rate remained almost unchanged, and in $40 \%$ of the rabbits there was a tendency to bradycardia. At the same time, the ECG indicators did not undergo significant changes. 
With prolonged exposure to vibration, a decrease in respiratory movements was also observed, especially after physical load.

Our studies on rabbits have shown that mid-frequency vibration (20, $40 \mathrm{~Hz}$ ) causes tachycardia. In this regard, interesting data were obtained in [6], according to which, during low-frequency vibration, the activity of the sympathetic nervous system (SNS) is inhibited and the tone of the parasympathetic nervous system prevails, leading to a decrease in blood pressure and bradycardia. At high frequencies, SNS excitation processes predominate, resulting in increased blood pressure and tachycardia. This is confirmed by experiments with stimulation of the posterior hypothalamus [7]. Against the background of the dynamic factor, the descending sympathicotropic discharge of the posterior hypothalamus on cardiac activity increases, and the bradycardic effect of the anterior hypothalamus is obscured.

Under the influence of vibration, the excitability of the respiratory center also changes. At medium and high vibration frequencies (40 and $80 \mathrm{~Hz}$ ), the amplitude and frequency of respiratory movements in rabbits significantly increase, and with prolonged exposure, they decrease. The main role in the development of these changes belongs to shifts in the functional state of the hypothalamic centers [8, 9].

According to [10], electrical stimulation of the ergotropic-dynamogenic zone of the posterior hypothalamus causes increased frequency and deepening of respiration, along with other reactions of activation of the SNS.

Along with the reflex nature of cardiac changes, the possibility of a direct action of mechanical shocks on the contractile myocardium and the pathways of the heart is assumed [11].

In addition to ECG data, the results on tissue metabolism and SDH activity obtained by us also testify to changes in the metabolism of the cardiac muscles. In the initial phase of vibration, there was an increase in oxygen uptake by the cardiac muscles, an increase in SDH activity, and a decrease at the end of vibration exposure. Phase changes in SDH indicate the effect of vibration on metabolic processes occurring at the level of enzymes in cardiac muscle cells.

Conclusion. Thus, the results of our studies have shown that under vibration exposure, phase changes in vegetative functions occur in rabbits, the nature and direction of which depends on the parameters of the dynamic factor.

Received 05.05.2021

Reviewed 16.07.2021

Accepted 30.07.2021

\section{REFERENCES}

1. Minasyan S.M. Integrative Structures of the Brain During Vibration. Yerevan: YSU Press (1990), 272 p. (in Russian)

2. Lutskiy I.S. Chronic Psychosocial Stress and the Development of Cerebrovascular Disorders. Dissertation for the Degree of Doctor of Medical Sciences. St. Petersburg (2019). (in Russian) https://www.dissercat.com/content/khronicheskii-psikhosotsialnyi-stress-i-razvitie-sosudistomozgovykh-narushenii 
3. Torkunova O.V. Cholinergic Regulation of Central Nervous System Dysfunctions Due to Exposure to Low-Frequency Acoustic Vibrations. Dissertation for the Degree of PHD in Medical Sciences. St. Petersburg (2019). (in Russian) https://www.dissercat.com/content/kholinergicheskaya-regulyatsiya-narushenii-funktsiitsentralnoi-nervnoi-sistemy-vsledstvie

4. Luk'yanova LD, Kol'tsova AV, et al. Influence of Space Flight Factors on the Functions of the Central Nervous System. Moscow: Nauka (1966), 272 p. (in Russian)

5. Ostroukhova V.A. Influence of Continuous and Intermittent Low-Frequency Jerky Vibration on Some Indicators of the State of Redox Processes in the Body. Occupational Hygiene (Gigiena Truda) (1972), no. 2, 99-109. (in Russian)

6. Volkov A.M. Volkov, A.M. Hygienic Regulation of Noise and Vibration of the Rolling Stock of Road Transport. Moscow: Medicine (1970), 251 p. (in Russian)

7. Minasyan S.M., Petrosyan L.A. The Functional State of the Cardiac Activity of Animals when Exposed to Vibration. Proc. YSU (1986), no. 2, 112-116. (in Russian)

8. Evans M.H, Pepler P.A. Respiratory Effects Mapped by Focal Stimulation in the Rostral Brain Stem of the Anaesthetised Rabbit. Brain Research 75 (1974), 41-57. https://doi.org/10.1016/0006-8993(74)90769-0

9. Budzińska K. Effects of Hyperthermia and Stimulation of The Hypothalamus on the Activity of the Phrenic Nerve in Hypo- Normo- and Hypercapnic Rabbits. Acta Neurobiol. Exp. 53 (1975), 227240.

PMID: 1163305

10. Hess W.R. Hypothalamus and Thalamus. Experimental Documentation. (2nd ed.) Stuttgart: Thieme (1969), $77 \mathrm{p}$.

11. Ullsperger P., Seidel H., Menzel G. Effect of Whole-Body Vibration with Different Frequencies and Intensities on Auditory Evoked Potentials and Heart Rate in Man. Eur. J. Appl. Physiol. Occup. Physiol. 54 (1986), 661-668.

https://doi.org/10.1007/bf00943357

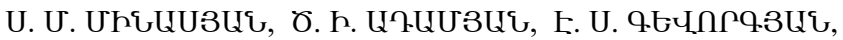

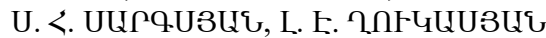

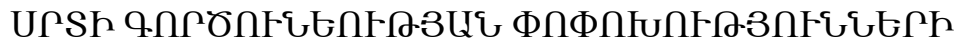

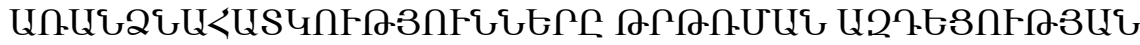 TUBULGGERกFU}

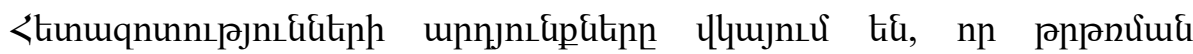

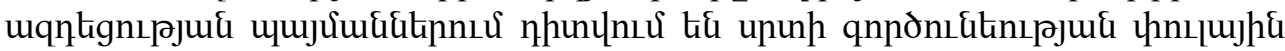

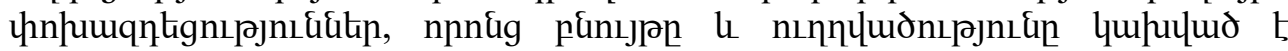

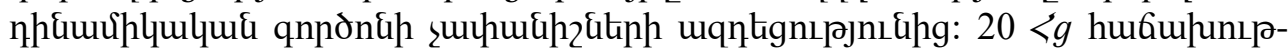

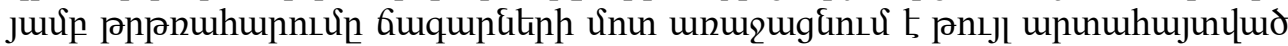

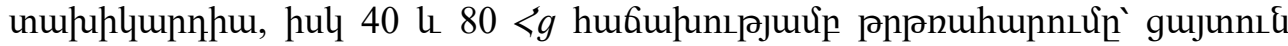

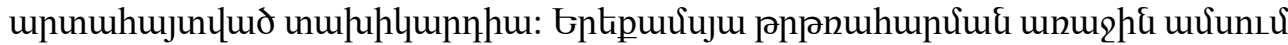

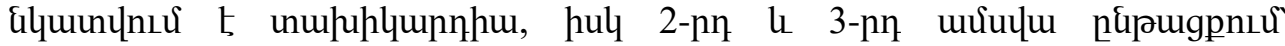

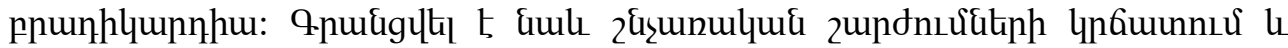

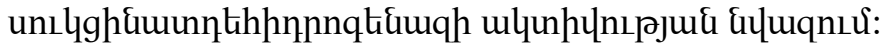


С. М. МИНАСЯН, Ц. И. АДАМЯН, Э. С. ГЕВОРКЯН,

С. Г. САРКИСЯН, Л. Э. ГУКАСЯН

\section{ОСОБЕННОСТИ ИЗМЕНЕНИЯ СЕРДЕЧНОЙ ДЕЯТЕЛЬНОСТИ ПРИ ВОЗДЕЙСТВИИ ВИБРАЦИИ}

Результаты исследования показали, что при воздействии вибрации у кроликов отмечаются изменения сердечной деятельности, характер и направленность которых зависит от параметров динамического фактора. Вибрация с частотой 20 Гц вызывает умеренную тахикардию, а 40 и 80 Гц выраженную тахикардию. Трехмесячная вибрация в первом месяце воздействия вызывает тахикардию, а при трехмесячном воздействии брадикардию. Также наблюдаются урежение дыхательных движений и снижение активности фермента сукцинатдегидрогеназы. 